\title{
Analysis of the market concentration of the container shipping markets - selected issues
}

\author{
Jędrzej Charłampowicz ${ }^{1}$ \\ ${ }^{1}$ Department of Logistics and Transports Systems, Gdynia Maritime University, 81-222 \\ Gdynia, Poland
}

\begin{abstract}
The value of maritime freight transport grows yearly both in terms of value and quantity. The dynamic development of container shipping is responsible for this state of affairs. The maritime container transport market is strongly integrated on the supply side. The aim of this paper is to determine, based on empirical data, whether the market is still competitive for its participants on the supply side. For this purpose, the 2 indicators of concentration were calculated, namely CRx-concentration for 4 operators with the largest market share, and Herfindahl-Hirshmann Index for TOP 10 and TOP 20 operators, based on AXS Alphaliner TOP100 and various issues of UNCTAD Review of Maritime Transport. The results of the calculations indicate that the market is still competitive, although it is heading towards a direction in which several large entities will dictate the conditions to other participants.
\end{abstract}

Key words: Herfindahl-Hirshmann Index, maritime container shipping market, competitiveness, concentration

\section{Introduction}

Maritime container shipping is one of the fastest developing transport branch. Introducing containers to the transportation process implied the need to change the existing transportation model in the way to enable integration of every branch $[1,2]$. This modification was conducted for every member of the transportation process. Firstly, it was made through readjustment of vessels for shipping containers and as a consequence also through readjustment of ports for their handling. This type of adaptive activities significantly reduced transportation costs [3]. Reducing transportation costs and time, thanks to markets integration, also accelerated further markets liberalization of global trade as well as opening up and developing new markets. Due to its characteristics containerization is considered to be the main factor and catalyst for globalization in $20^{\text {th }}$ century [4]. The dynamic growth of the new transportation branch caused an increase in a number of markets members on the supply side as well as on the demand side. The supply side of the market took actions to strengthen their market shares and risk sharing [5]. In $21^{\text {th }}$ century those activities were carried out by establishing strategic alliances that led to the reduction costs and increase market shares battening on the smaller entities. For needs of 
this paper the supply side of maritime container shipping markets (MCSM), taken into account during conducted research, is defined as follows: all vessel operating common carriers transporting containers (filled or empty), with various but standardized sizes/dimensions regardless of the content, put into service on a regular basis, loading and discharging at specified ports.

The aim of this paper is to verify, based on available empirical data, such as market share of the maritime container carriers, whether the supply side of the maritime container shipping markets is still globally competitive for its participants and detect the trend of market concentration.

This paper is divided as follows:

- Section 2 provides brief characteristics of the supply side of the MCSM;

- Section 3 describes methodology and data;

- Section 4 presents results of calculations;

- Section 5 outlines research limitations and further research directions;

- Section 6 shows final conclusions.

\section{The supply side of the maritime container shipping markets}

The average increase in sea freight during period 2005-2016, in million loaded tones, was 5,2 per cent. In 2016 global containerized trade expanded 3,2 per cent year-to-year, with volumes attaining an estimated 140 million TEU's [6]. [7] notes that MCSM are currently a strongly integrated markets, the main reasons of this state of affairs are increasing transportation capacity and increasing share of high-value goods in transported cargoes. Table 1 presents the change of quantity and capacity of container vessels in last decade. Despite of decrease the number of vessels scheduled to be deployed in 4Q2017 by around 4,3 per cent compared to 4Q 2007, during period 2007-2017 there was significant increase in total deployed capacity from 123,2 mil TEU to 183,8 mil TEU, which is almost 50 per cent growth [8].

Table 1. Number of vessels based on their capacity

\begin{tabular}{|c|c|c|c|}
\hline \multirow{4}{*}{ Number of vessels } & Ship size (TEU) & 4Q 2007 & 4Q 2017 \\
\cline { 2 - 4 } & $<5000$ & 4589 & 3523 \\
\cline { 2 - 4 } & $5000-7499$ & 328 & 469 \\
\cline { 2 - 4 } & $7500-9999$ & 172 & 527 \\
\cline { 2 - 4 } & $10000-12499$ & 0 & 96 \\
\cline { 2 - 4 } & $12500-14999$ & 8 & 172 \\
\hline Total no of vessels & $15000+$ & 0 & 92 \\
\hline
\end{tabular}

Source: [8]

Placing higher orders for container ships in recent years has caused an oversupply. The trend of ordering gearless ships has been sustained. Although, in 2016, TEU capacity per delivered ship was 12 per cent lower than in 2015, the new vessels are larger than existing fleet [6]. This state of affairs continues to exert pressure on ports to accommodate to larger vessels and, what is important, due to cascading effect, this trend applies also on smaller ports. The main reason of introducing mega container ships was the need of achieving the economies of scale. Oversupplied market characterized by the mega container ships (over 18000 TEU) and weak demand growth effected in the need for consolidation and rationalization to optimize capacity and reduce costs [6]. Ways to achieve those goals were 
mergers and acquisitions (M\&A) and shake-ups in the liner shipping alliances. Implementation of mega container ships changed overall dynamics of MCSM.

The MCSM has to face very volatile and rapidly changing market realities [9], the way of dealing with these conditions is strong concentration on the supply side. It can be expressed in twofold: subjective capital integration and organizational and functional form expressed through establishing strategic alliances. Main reasons for those agreements are risk-sharing, knowledge exchange, economies of scale and strengthening the market position [5]. Concluding, the above settlements have high impact on MCSM. First, it is reducing cost and risk for alliance participants, that are generally top operators. This also affects on smaller enterprises, which cannot draw benefits from economies of the scale and risk-sharing.

The MCSMs have witnessed unique transformations unheard of in any other transportation sector. Through M\&A, as well as formation of alliances, the three major alliances, namely 2M Alliance (Maersk, MSC), THE Alliance (NYK, MOL, K Line, Yang Ming, Hapag-Lloyd) and Ocean Alliance (CMA CGM, Evergreen, OOCL, COSCO), represents almost $80 \%$ of global container capacity. Some M\&A requires the alliance to be reorganized [3].

\section{Methodology and data}

\subsection{Market concentration}

Market concentration refers to the extent of which small number of enterprises account for large proportion of provision of goods or/and services [10]. The theory of industrial organization economics suggest that higher level of market concentration will lead entities to monopolistic practices, that will result in misallocation of resources and poor economic performance. The ownership concentration, which is related to the supply side of market, measures the degree of market control and can be evaluated using concentration indexes [10]. To determine the degree of concentration two concentration indicators are calculated.

\subsection{Concentration ratio}

Concentration ratio $\left(\mathrm{CR}_{\mathrm{x}}\right)$ is one of the most popular and simplest methods for judging the degree of concentration. Generally the $\mathrm{CR}_{\mathrm{x}}$ is used for computing the relative share of industry accounted for the $x$ largest firms. One of the most prominent indicators is the fourfirms concentration ratio $\left(\mathrm{CR}_{4}\right)$ which involves totaling up the market shares of four largest entities in the industry. Mathematical formula for calculating $\mathrm{CR}_{4}$ can be written as follows:

$$
C R 4=\sum_{n=1}^{4} s_{\mathrm{i}}
$$

where $s_{i}$ represents the percentage market share of the $i^{\text {th }}$ carrier. The main disadvantage of this indicator is lack of ability to show the total number of competitors on the market, since it is focused only on the top entities [10].

\subsection{Herfindahl-Hirshman Index}

Herfindahl-Hirshman Index (HHI) is based on the total number and market share of enterprises in the industry. This indicator is typically used by the regulators to provide an 
assessment of market concentration $[10,11]$. It is computed as a sum of the squares of percentage market shares of entities in the studied business. Mathematical formula for HHI is as follows:

$$
H H I=\sum_{i=1}^{n} s_{\mathrm{i}}^{2}
$$

where $n$ stands for total number of examined carriers and $s_{i}$ represents the percentage market share of the $i^{\text {th }}$ carrier. The maximum value of HHI, according to equation 2, is 10000, which stands for pure monopoly [10]. HHI below 1000 represents unconcentrated competitive market, value between 1000 and 1800 indicates moderately concentrated market and value above 1800 shows highly concentrated market [11].

\subsection{Data description}

Data used for calculating CR4 and HHI comes from publicly available sources such as: AXS Alphaliner TOP100, and various issues of Review of Maritime Transport published yearly by UNCTAD. The data used for calculations includes market share of examined operators. The concentration indexes are computed over the period of 2010-2018. For computing HHI only operators having at least $1 \%$ of market share were taken into account. The reason for this procedure is the fact, that squaring market shares of less than $1 \%$ has no significant impact on total HHI. As the result, where the MCSM is concerned, only TOP 20 operators market share can be calculated without affecting the whole image of market concentration.

\section{Results}

Computation has been made using data concerning market share[6, 12-19]. Table 2 presents results of calculations of HHI TOP10 and TOP 20 operators and CR4. Conclusion made on basis of this calculation shows clearly that average increase of concentration, year-to-year, is around 13 per cent for TOP10 operators and 12 per cent for TOP20 carriers. Figure 1 presents the evolution of the Herfindahl-Hirshman Index.

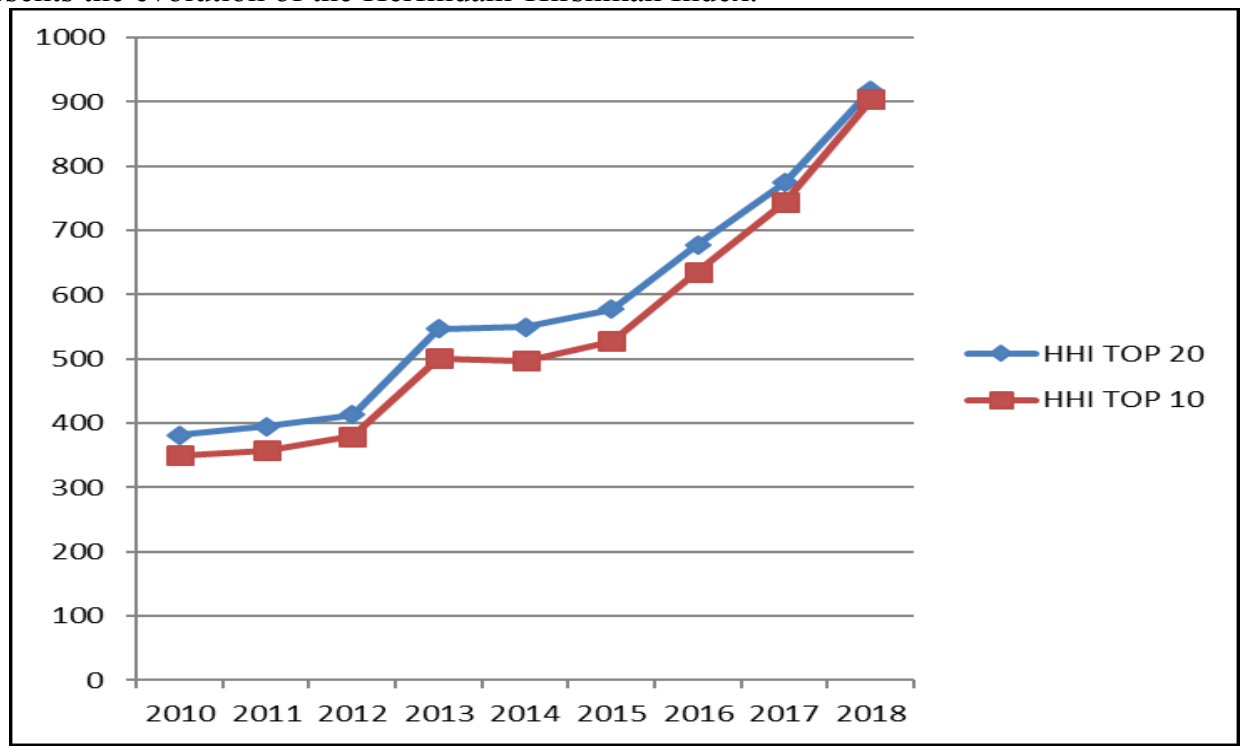


Fig. 1. Evolution of Herfindahl-Hirshman Index

Table 2. Measurement of concentration

\begin{tabular}{|c|c|c|c|c|c|c|c|c|c|}
\hline & $\mathbf{2 0 1 0}$ & $\mathbf{2 0 1 1}$ & $\mathbf{2 0 1 2}$ & $\mathbf{2 0 1 3}$ & $\mathbf{2 0 1 4}$ & $\mathbf{2 0 1 5}$ & $\mathbf{2 0 1 6}$ & $\mathbf{2 0 1 7}$ & $\mathbf{2 0 1 8}$ \\
\hline $\begin{array}{c}\text { HHI } \\
\text { TOP10 }\end{array}$ & 350 & 357,54 & 379,89 & 501,12 & 497,12 & 527,66 & 635,52 & 744 & 904,34 \\
\hline $\begin{array}{c}\text { HHI } \\
\text { TOP20 }\end{array}$ & 381,18 & 394,92 & 413,2 & 546,57 & 549,93 & 577,08 & 678,52 & 774,74 & 918,49 \\
\hline CR4 & $32,1 \%$ & $32,3 \%$ & $33 \%$ & $38 \%$ & $38,8 \%$ & $39,75 \%$ & $45,5 \%$ & $49,7 \%$ & $54,2 \%$ \\
\hline
\end{tabular}

Current value of HHI for TOP 10 and TOP 20 is still below value 1000, which means that market is still competitive, although CR4 in March 2018 is 54,2 per cent, that refers to situation where more than half of the market is controlled by four largest entities. In 2010 50,2 per cent of the market was controlled by top 10 operators [19], in 20137 largest liner companies had 49,8 per cent [16].

\section{Research limitations and further research directions}

\subsection{Research limitations}

The ability to utilize and have a full access to Science Direct journals made it possible to review the subject in interesting areas. None the less, the fact of relying on only one database greatly limited the possibility of conducting a more extensive literature research.

Another research limitation is the lack of access to full database of AXS Alphaliner and possibility to conduct research based on publicly available reports like UNCTAD Review of Maritime Transport and briefs reports such as MDS Transmodal Container Shipping Bulletin and, mentioned above, AXS Alphaliner.

\subsection{Further research directions}

It is necessary to conduct two-directional research about the impact of strategic alliances on global market concentration as well as on the main trade lanes. Additionally, it is crucial to determine the impact of strategic alliances on efficiency of the supply chains passing through MCSM [2], which are the main catalyst for the global trade development.

\section{Conclusions}

MCSM have to face the volatile, rapidly changing global trade environment, which is propelled by increasing customers requirements, technology advances, political disruptions and intensifying competition. For markets participants reducing cost has become the most important factor. The adaptation of the supply side of the MCSM was made by deploying ever-larger container vessels and consolidation.

The aim of this paper was to determine the global market concentration on the MCSM using 2 concentration indexes, namely Herfindahl-Hirshman Index and Concentration Ratio for 4 largest entities. The results of the calculations indicate that market is still competitive for its participants. Current value of the TOP20 HHI is below 1000, although it is clear that this rate is growing rapidly in period 2010-2018 having average pace of about 12 per cent. The TOP20 HHI value of 918,49 (919,9 for TOP50) represents fragmentized, unconcentrated, competitive market. Albeit, the largest liner companies capture dominant 
market shares. It can be stated that this trend of increasing market concentration will continue.

The main conclusions of this paper are:

- MCSM heading towards to more concentrated market, where few operators will dictate the conditions for other participants;

- It is important to determine the impact of strategic alliances on market concentration and market competitiveness with respect to global trade and main trade lanes.

\section{References}

1. T. E. Notteboom, Container Shipping in W. K. Talley (Ed.) The Blackwell Companion to Maritime Economics, 32 (2012)

2. J. Charłampowicz, Proceedings of the $17^{\text {th }}$ International Scientific Conference Business Logistics in Modern Management, 13 (2017)

3. C.-Y. Lee, P.-D. Song, Trans. Res. P. B, 95, 33 (2017)

4. D. M. Bernhoffen, Z. El-Sahli, R. Kneller, J. of Int. Ec., 98, 14 (2016)

5. P. Rau, S. Spinler, Trans. Res. P. E, 101, 21 (2017)

6. UNCTAD, Rev. of Mar. Trans., (2017)

7. A. S. Grzelakowski, Int. Bus. and Gl. Ec., 32, 20 (2013)

8. MDS, Transmod. Cont. Ship. Bul., November (2017)

9. T. E. Notteboom, Rev. of Net. Ec., 3, 21 (2004)

10. http://www.oecd.org/regreform/sectors/2376087.pdf - access March, 4, 2018

11. U. Qazi, M. Jahanzaib, W. Ahmad, S. Hussain, Ren. and Sust. En. Rev., 70, 13 (2017)

12. https://alphaliner.axsmarine.com/PublicTop100/ - access February, 14, 2018

13. UNCTAD, Rev. of Mar. Trans., (2016)

14. UNCTAD, Rev. of Mar. Trans., (2015)

15. UNCTAD, Rev. of Mar. Trans., (2014)

16. UNCTAD, Rev. of Mar. Trans., (2013)

17. UNCTAD, Rev. of Mar. Trans., (2012)

18. UNCTAD, Rev. of Mar. Trans., (2011)

19. UNCTAD, Rev. of Mar. Trans., (2010) 